\title{
MÁTÉSZALKA, A SIKERES VÁROS - IGAZI SIKER-E VAGY CSAK REMÉNYTKELTŐ KITÖRÉSI KÍSÉRLET? ${ }^{1}$
}

\author{
(Mátészalka, the Successful City - Is It a Real Success, \\ or Just a Hoping Breaking Through Attempt?)
}

\section{BARANYI BÉLA - BALCSÓK ISTVÁN}

\section{Bevezetés}

A területi tudományok mủvelői körében meglehetősen elterjedt álláspont, hogy a keleti, s még inkább az északkeleti országrész gazdaságában és társadalmában lejátszódott, illetöleg a jelenben zajló folyamatok kedvezőtlenül hatottak, sőt még ma sem kedveznek a fejlettebb térségekhez történö felzárkózás számára. A régtől fogva meglévő távolságok tovább nönek, vagy legalábbis konzerválódnak ma is, s a területi periferizálódás veszélye fenyeget kiterjedt alföldi területeket, nagy és kistérségeket egyaránt. Ez a körülmény szerepet játszott az Alföld nagyrégió iránti tudományos érdeklődés ébrentartásában, sőt élénkülésében, amit az is jelez, hogy a régióra irányuló vizsgálatok helyet kaptak az MTA hároméves (1997-1999) nagyszabású Nemzeti Stratégiai Kutatások Programjában is, „Új környezeti, gazdasági, települési és társadalmi folyamatok az Alföldön" címmel. A közkeletü elnevezéssel Alföld II. Kutatási Programnak keresztelt projekt keretei között a Debreceni Csoport koordinálása mellett folyt az ún. „határmente program", amelynek komplex köztük széles körü kérdöíves - vizsgálatai az Északkelet-Alföld határ menti területeire és településeire irányultak, $s$ föbb eredményei részben már hozzáférhetőek (Baranyi 1999; Baranyi-Balcsók-Dancs-Mezö 1999).

Az Alföld II. kutatási program keretei között végzett másik jelentös tudományos feladat "A sikeres városok az Alföldön" címü kutatás megkezdése volt, amelyet jórészt Enyedi György akadémikus ez irányú gondolatai inspiráltak. A különböző szempontok és tényezők alapján az MTA RKK ATI négy kutatóhelye által, a rendszerváltást követő időszakban, a gazdasági-társadalmi fejlettségét tekintve sikeresnek ítélt öt alföldi város, illetőleg közvetlen vonzáskörzetükből kijelölt két-két település, Gyula (Kötegyán, Elek), Kalocsa (Foktó, Szakmár), Mátészalka (Jármi, Ópályi), Szeged (Domaszék, Deszk) valamint Szolnok (Tószeg, Besenyszög) közül a Debreceni Csoport a "Szatmár fövárosaként" is emlegetett Mátészalka feldolgozását kapta feladatul.

A kutatásba bevont városok kiválasztása egy, a fejlettségi kritériumokat meghatározó sokváltozós statisztikai eljárással történt, kijelölve valamennyi város vonzáskörzetéből egy „magasan fejlett” (Mátészalka esetében Ópályi) és egy „,alacsonyan 
fejlett" (Jármi) települést, hogy példájukon keresztül vizsgálható legyen a kiemelt „sikeres városoknak” a közvetlen környezetükre gyakorolt, a sikeresség elemeit továbbadó kisugárzó hatása. A sikeresség okait és tényezőit vizsgáló jelenlegi esettanulmány tehát Mátészalkára és a város agglomerációs övezetében található két településre (Jármira és Ópályira) vonatkozó elemzések eredményeit tartalmaz$z a$. A tanulmány a város és a két falu múltját, jelenét és a jövöbeni továbbfejlödési esélyeit a rendelkezésre álló feldolgozások, statisztikai adatok, valamint az Alföld II. kutatási program részeként, az MTA RKK Alföldi Tudományos Intézetének a Szonda Ipsos segitségével elkészített kérdöives felmérése és az MTA RKK ATI Debreceni Csoportja által, a települések fejlődését meghatározó intézmények, gazdálkodó szervezetek vezetöivel készitett interjúk alapján mutatja be, mintegy bizonyságát adva annak, hogy a figyelemre méltó sikeresség ma még Mátészalka esetében is fölöttébb relativ, szigetszerü jelenség, hatása közvetlen környezetére meglehetösen esetleges. Igazi kitörésről, a helyi gazdasági-társadalmi élet egészét átható „nekilendülésröl” még aligha lehet szó.

A vizsgálatok célja annak megismerése volt, hogy a rendelkezésre álló adatok alapján a fejlödésre leginkább esélyes városok és környezetük valóban fel tudják-e mutatni a töretlen fejlödés jövöbe mutató jeleit, illetve rendelkeznek-e a sikerességet meghatározó alapvetö tényezökkel? Esetünkben még fontosabbá teszi a kérdések megválaszolását az a tény, hogy Mátészalka még az Alföld egészénél is jóval fejletlenebb térségben mutatja fel a sikeresség ismérveit. Fokozott jelentöséggel bír tehát annak eldöntése, hogy a város csak szükebb környezetéhez mérten tekinthetö-e fejlödőképesnek, vagy az Alföld egészéhez viszonyítva is? Az utóbbi esetben ugyanis képes lehetne a tágabb környezet, az egész szabolcs-szatmár-beregi térség megújulásának elősegítésére.

\section{A sikerröl és a sikerességröl}

A bevezetöben, a „sikerességröl” tett megjegyzés kapcsán, ha még röviden is, fontos néhány szót ejteni arról, hogy tulajdonképpen milyen településeket tekinthetünk sikeresnek, illetve hogyan is kell értelmeznünk a sikeresség - minden bizonnyal relatív - fogalmát? A ,Mi a siker?" kérdés titkait keresve, a témával mindezideig legbehatóbban foglalkozó Enyedi György szerint a városok versenye mindig nyerteseket és veszteseket jelent - a nyertesek a sikeres városok. Véleményünk szerint összhangban az elöző megállapításokkal - a ,sikeres város" jelzö azokra a településekre igaz, amelyek a leginkább tudtak és tudnak alkalmazkodni a politikai-gazdasági-társadalmi változások teremtette új helyzetekhez, vagyis sikeresen válaszolnak a felmerülő kihívásokra.

A sikeresség természetesen minden esetben relatív, de konkrét adatok alapján mégis mérhetö fogalom, és ebben leginkább a statisztikai mutatók, faktoranalízisek és a lakosság véleményét tükröző felmérések és interjúk nyújthatnak segítséget. Egy-egy település fejlődésének dinamizmusát azonban csak akkor lehet igazán jól érzékelni, ha nemcsak korábbi önmagához, hanem szükebb és tágabb környezeté- 
hez viszonyitva is vizsgáljuk az elörelépést - vagy éppen a visszafejlődést. Így jobban megérthetjük a sikeresség okait és körülményeit, emellett pedig a telepúlés sikerességének egy újabb mércéjéhez juthatunk: képes-e az adott város fejlődésének pozitív eredményeit közvetíteni a közvetlen környezetében levő többi település irányába, képes-e a saját holdudvarát is dinamizálni, avagy sikeressége csupán önmagára korlátozódó szigetszerủ jelenség?

Egy városnak és a környezetének fejlödöképessége, sikeressége számos szempont alapján értékelhető. Enyedi akadémikus a siker tíz, egymással szorosan összefüggő tényezöjét említi meg, amelyek együttes jelenléte biztosítja $A$ VÁROS sikerét (Enyedi 1997, 2-5). Ezek a következök: 1) A sikeres város képes a gazdasági szerkezet változtatására; 2) A sikeres város szolgáltató szektorában magas az értékhúzó ágazatok aránya; 3) A sikeres várost a tudás-alapú termelés jellemzi; 4) A sikeres városban erōs az innovációs képesség; 5) A sikeres városban döntések születnek; 6) A sikeres városban erös és gyarapodó a középosztály; 7) A sikeres város nagy értékü környezetet nyújt és színvonalas közszolgáltatást biztosit, $\mathrm{s}$ ez elsörendủ gazdaságfejlesztő tényező is; 8) A sikeres város jól kezeli konfliktusait; 9) A sikeres városnak jelentősek a külső kapcsolatai; 10) A sikeres városban növekszik a jövedelem és a foglalkoztatás.

A város-siker tíz tényezöjét összegezve az tekinthető sikeres városnak, amelyben növekszik az elöállított jövedelem, e jövedelem jelentős része helyben marad újrabefektetésre, vállalkozói- és személyi jövedelemre, adók formájában városmüködtetésre és fejlesztésre, a személyi jövedelemnövekedésböl a lakosság széles rétegei részesülnek, s e gazdasági növekedés nem károsítja a város természeti, épített és kulturális környezetét (Enyedi 1997, 6).

A rendszerváltás nyomán kialakuló új körülmények között egyre inkảbb kiélezödött versenyhelyzetböl kiindulva joggal tarthatók azok a városok sikeresnek, amelyek a települések közötti versenyben a gyöztesek táborába tartoznak. A siker mércéje tehát a gyors alkalmazkodóképesség mellett a megfelelö érdekérvényesités, a helyi adottságok minél jobb kihasználása. Amennyiben az adott település képes megbirkózni ezekkel a feladatokkal, úgy a sikeresség valóban kézzelfoghatóvá válik, és külső jegyekben is megnyilvánul. Ilyennek tekinthető a hosszú távú és stabil jövedelemnövelés, a népességnövekedés és az ezt kísérö foglalkoztatásbövülés, valamint a nemzetközi és a kulturális szerep erösödése.

A sikerességnek természetesen nem csupán kifelé megnyilvánuló eredményei, hanem a fejlödést alapjaiban meghatározó tényezöi is vannak. Az új körülményekhez való sikeres alkalmazkodást eröteljesen befolyásolja többek között az, hogy az adott településen végbement-e az ágazati struktúra átalakulása, a gazdasági szerkezetváltás; és hogy az ennek során fellépö megrázkódtatásokat tudták-e megfelelöen kezelni? Fontos kérdés, hogy a szerkezeti váltás során kellően megerösödött-e a tercier szektor, és megjelentek-e a tercier tevékenység bizonyos modern elemei, amelyek biztosíthatják a további fejlödést. Az sem mellékes, hogy a gazdasági 
ágakban mennyire előrehaladott a versenyképességet biztositó elengedhetetlen innovációs és technológiai váltás.

A gazdasági élet dinamikus fejlödéséhez elengedhetetlenül szükség van a döntéshozó gazdasági hatalom jelenlétére, a város és térségének fejlődését befolyásolni képes megfelelő koncentrációjára, amely felsöbb szinteken is megfelelően képviselni tudja településének érdekeit. Ennek a kellő szintü megléte biztosítékot jelenthet a gazdasági életnek a mai kor követelményeinek megfelelö, tudás-alapú termelésre történö átállitására, ami a sikeresség szempontjából kulcskérdésnek számít. A tudás-alapú termelés nem képzelhetỏ el a szükséges emberi töke, a kitermelt magasan kvalifikált munkaerö, illetve az ennek megtartására szolgáló minél jobb életkörülmények biztosítása nélkül, és csak az erre kellö figyelmet fordító települések őrizhetik meg továbbfejlödési esélyeiket a jövöre nézve.

A gazdasági élet sikeressége alapvetően befolyásolja a településen élök életminőségének, mindennapjainak alakulását, mivel ez elszakíthatatlanul erős szálakkal kötődik a jövedelmek és a foglalkoztatás szintjéhez, ami döntően a helyi gazdaság teljesítőképességének függvénye. Ezek a tényezők pedig meghatározzák a helyi társadalom szerkezetét és összetételét; hatással vannak többek között a polarizáltság, a jövedelmi különbségek mértékére, valamint arra, hogy kialakulhat-e egy erōs, a változásokat továbbvinni akaró és támogatni képes, helyi öntudattal rendelkezö középosztály. Ezért fontos kérdés, hogy milyen irányba hatnak a környezeti és anyagi, ezeken keresztül pedig az életkörülmények változásai: támogatják-e ezeket a folyamatokat, vagy éppen az ellentétes irányba hatnak? A helyi önkormányzatoknak abban van óriási szerepe, hogy milyen hatásfokkal képesek kezelni a környezeti változások folyamán fellépỏ negatív externáliákat (kömyezetszennyezés, a közlekedés és tömegközlekedés problémái stb.), mert ez a jövőben mindinkább meghatározó tényezővé válik a lakónépesség megtartásának, illetve gyarapitásának tekintetében.

A városon belül jelentkező tendenciák mellett figyelmet kell fordítani a város és környéke külsö kapcsolatrendszerének ápolására, fejlesztésére. Ez egyaránt vonatkozik a legszükebb és a legtágabb (a határokon túlnyúló) környezettel való harmonikus együttmüködésre (közös beruházások, oktatás, turizmus stb.). Az informatika rohamos fejlödése miatt nem lehet sikeres az a település, amelyik nem tud hatékonyan hozzákapcsolódni a nagyobb innovációs központokhoz. Ez azonban csak akkor következhet be, ha biztosítani tudják az információk szabad és gyors áramlását; tehát az elektronikus elérhetőséget is a lehetö legmagasabb szintre kell fejleszteni, hogy minél zavartalanabb legyen a kapcsolattartás a központi hatalommal, és minél gyorsabban lehessen reagálni a változásokra.

\section{Múlt és jelen, avagy a kialakult helyzet föbb jellemzöi}

Mátészalka Magyarország északkeleti részén, Szabolcs-Szatmár-Bereg megyében, a történelmi Szatmár vármegye nyugati határán, a Kraszna nyugati partján helyezkedik el. Természetföldrajzilag a magasabban fekvő homokdombos Nyírség 
és a mélyebben fekvő vizenyős, lápos területekkel tarkított Szatmári-síkság határán fekszik. A 960 hektár belterületü (külterülete mintegy 3200 hektár), közel 20 ezer lakosú várost „Szatmár fövárosaként” is emlegetik. Nem minden alap nélkül, hiszen Mátészalka 1920 és 1950 között a megcsonkolt Szatmár-Bereg-Ugocsa vármegye székhelye volt, és ma az öt övezỏ hozzávetőleg 85 ezer lakost számláló kistérség valóságos gazdasági és kulturális központja, a megye második legnagyobb városa. Ennek megfelelöen számos közhivatal müködik a településen (városi bíróság, ügyészség, rendörkapitányság, körzeti földhivatal, állat- és növényegészségügyi szolgálat, tisztiorvosi hivatal, vám- és pénzügyőrség), melyek hatásköre jóval túlnyúlik a város határain. Ugyanez mondható el a közelmúltban felújított és korszerüsített 485 ágyas területi kórházról és a több mint 2000 diákot befogadó négy középiskoláról is.

A decentrum funkciók betöltésére és a kiemelt térségi feladatok ellátására tökéletesen alkalmassá teszi nagyon kedvezö földrajzi fekvése. A Szabolcs-SzatmárBereg megye északkeleti-délnyugati tengelyén elhelyezkedö város régtöl fogva fontos szerepet játszott az északi és a keleti irányú forgalomban. Területén öt vasútvonal, valamint két föközlekedési és több mellékútvonal találkozik. Emellett gazdaság- és településföldrajzi pozícióját nagymértékben erösíti a határközeli fekvés. Románia 30 kilométer távolságra, Ukrajna pedig mintegy 50 kilométernyire érhetö el közforgalmi határátkelöhelyen keresztül.

Igen elönyös földrajzi fekvése akkor válik még szembetünőbbé, ha megvizsgáljuk a sajátos megyei településszerkezetben elfoglalt helyét. Szabolcs-Szatmár-Bereg településhálózatát a közepes és az aprófalvak nagy száma jellemzi, párosulva a külterületek még mindig magas arányával. Ugyanakkor 1969-ig nem beszélhettünk a megyében városhálózatról, mivel addig az egyetlen városi rangú település a megyeszékhely Nyíregyháza volt. Jó két évtizedig a 10-13 ezer lakosú járásszékhelyek jelentették csak a városhálózat egy-egy lehetséges láncszemét a megyében. Végül 1969-ben kapta vissza egykori városi rangját Mátészalka, majd 1970-ben Kisvárda, 1973-ban pedig Nyírbátor nyerte el a városi címet. Napjainkig is ezek a települések tekinthetök középfokú megyei központoknak, és hozzájuk zárkózott fel idöközben Fehérgyarmat, Tiszavasvári, Vásárosnamény és Záhony.

A városok számának rohamos gyarapodása azonban csak a rendszerváltás után indult meg - erre a rangra emelve néhány olyan települést is, amelyek de facto ma sem tekinthetök annak (Baktalórántháza, Máriapócs, lbrány stb.). Mátészalka esetében azonban ez a megállapítás nem áll fenn már csak azért sem, mert a DebrecenNyíregyháza-Záhony tengely mellett kialakult Nyírbátor-Mátészalka-Fehérgyarmat erövonal központi településévé vált.

A jelenlegi város helyén már a X-XI. század óta található egybefüggő lakott terület, bár a kora középkorban ez még két falura, Mátéra és Szalkára tagolódott. A települések 1268-ig a király birtokában voltak, és eladományozásuk után nem sokkal már jelentős lakott helynek számítottak, különösen az 1270-es években megkapott csütörtöknapi vásártartási jog révén. A kedvezö földrajzi, a városvonalak 
menti vagy ahhoz közeli fekvés miatt gyorsan fejlödött Szalka. Az 1380-as évek eleje és az 1560-as évek között már megmutatkoztak a mezövárosi fejlödés jelei, de csak 1498-ban nevezi egy oklevél Szalkát oppidumnak (más források szerint a korabeli iratok alapján már 1408-tól mezővárosi rangot kapott). Ezt a fejlődést az ország három részre szakadása és az ezt követő zürzavaros idöszak akasztotta meg csaknem véglegesen. 1705-ben ugyanis mindössze öt embert találtak a településen, 1786-ban (az első hivatalos népszámlálás idején) viszont már 1325 lakost számoltak össze.

$\mathrm{Az}$ igazán látványos fejlödés a XIX. század végétöl, a dualizmus időszakában felgyorsuló urbanizációs folyamatok eredménye, mindenekelött a század utolsó negyede volt sikeres korszaka a városnak. Ez volt a polgári városiasodás időszaka, amikor a település lakossága megháromszorozódott, és ebben az idöben nyerte el mai arculatát is. Ekkor épültek ki a város életében máig jelentős szerepet játszó vasútvonalak, korszerủ mezögazdasági gyártelep létesült, és ezek nyomán dinamikusan fejlődött a mezőgazdaság és a kereskedelem. Jól jelzi a település sikerességét az a tény, hogy a mai Magyarország területén elsőként itt indult meg 1888-ban a közcélú villamosenergia-szolgáltatás.

A „látványos fejlesztések negyedszázada" megismétlődött akkor is, amikor Mátészalka kényszerủségből az anyaországtól elszakított Nagykároly helyett 1923 és 1940, majd pedig 1945 és 1950 között - a trianoni békekötés következtében - a megcsonkult Szatmár, Bereg és Ugocsa vármegyék székhelye volt. A második világháború utáni évek nagyszabású közigazgatási átszervezései, illetőleg a megyerendszer át- és újraszervezése nyomán Szabolcs-Ung és Szatmár-Bereg-Ugocsa megye 1950. március 15-én, Nyiregyháza székhellyel, Szabolcs-Szatmár néven egyesült. Ezt követően azonban jelentős visszaesés következett: Mátészalka elveszítette városi rangját, és járási szerepkörü nagyközségként funkcionált egészen 1969-ig. Az ekkor ismételten megszerzett városi jogállás újabb jelentős lökést adott a település fejlődésének. Az akkoriban indult és a rendszerváltásig töretlenül tartó erőteljes és eredményes városfejlesztő tevékenység a lakosság és a külső szemlélő számára egyaránt egyértelmủ volt, ahogyan azt az 1981-ben elnyert Hild János emlékérem is bizonyítja.

A megújult településföldrajzi szerepkör a város gazdasági életére is jótékony hatást gyakorolt, különösen az 1970-es évek ipartelepítési programjának köszönhetöen. Ekkor alakították $k i-$ az országos tendenciát évekkel megelözve - azt az igényeknek megfelelöen közmüvesitett ipartelepet, amely megfelelö alapul szolgált a mai ipari park létrehozásához. A terület kiválasztásánál már akkoriban figyelembe vették a környezetvédelmi követelményeket, a városrendezési szempontokat, illetve a terület bővitési és továbbfejlesztési lehetőségeit.

A mintegy 100 hektáros ipartelepet gyorsan benépesítették az akkori - föleg budapesti központú - állami nagyvállalatok: jelentös telephellyel rendelkezett az ERDÉRT, itt volt a Szamos menti Állami Tangazdaság központi telephelye, és igen számottevő beruházások keretében települt ide a Szatmár Bútorgyár, a Budapesti 
Finomkötöttáru Gyár és a Magyar Optikai Müvek (csak ez az üzem mintegy 1500 fót foglalkoztatott) egy-egy gyáregysége. Az 1970-es évtized végén nekilendült ipar egészen a rendszerváltásig prosperált, de $a$ rendszerváltással együtt járó szervezeti és szerkezeti átalakulás gyakorlatilag valamennyi üzemet maga alá temette, és ezt a visszaesést csak nehezen tudja kiheverni a város, hiszen máig ható súlyos következményei vannak (munkanélküliség stb.).

Ha egy város sikerességét annak alapján mérjuk, hogy képes-e eredményei folytán gyarapítani a népességét, akkor Mátészalka nem pályázhatna erre a címre. 1990-ben 19069 fö, 1994-ben 18386 fö, 1998. január 1-én pedig 18191 fö volt a város lakónépessége, vagyis nyolc év alatt 4,6\%-os volt a visszaesés, ugyanekkor a megye más városaiban $1,3 \%$-os volt a csökkenés, a megye egészére pedig a stagnálás volt a jellemzö. Az 1000 lakosra számított természetes szaporodás üteme folyamatosan csökkent (értéke 1990-ben 4,2, 1994-ben 1,8 fö), 1997-ben már igaz szerény mértékü - természetes fogyást $(-0,5)$ figyelhetünk meg. A népesség korcsoportonkénti megoszlása azonban még mindig kedvezönek mondható: a munkaképes korosztály aránya mintegy 8\%-kal haladja meg a megyei átlagot $(73,6 \%)$, a 60 éven felülieké pedig 5\%-kal marad alatta (12,7\%). Ebben, a népesedési szokásokat ismerve valószínüleg nagy szerepet játszik a jelenleg mintegy $6 \%$-ra tehető roma etnikum is.

A népességcsökkenést azonban mindenekelött az eröteljes elvándorlás okozza, mivel az 1000 lakosra vetített vándorlási különbözet értéke 1990-ben -14,3, 1994-ben -8,6, 1997-ben pedig -15,2 fö volt. Mindez akkor válik különösen figyelemreméltóvá, ha hozzátesszük, hogy Szabolcs-Szatmár-Bereg 1997-es mutatója mindössze $-0,9$ ezrelék. Az elvándorlásnak számos tényezője van: a környezö falvakban alacsonyabbak a telek- és ingatlanárak és valamivel olcsóbb a megélhetés. Az egyik legfontosabb tényezỏ éppen a város fejlödésére, illetve annak a közvetlen környezetére való kisugárzására vezethetỏ vissza.

Ezeken a kisebb telepuléseken szinte minden megvan (infrastruktúra, szolgáltatás stb.), ami a városi létformát jellemzi, és az utóbbi évtized fejlesztései nyomán néhány településen már megközelítették, bizonyos területeken pedig túl is haladták a városban tapasztalható szintet. Ez a megállapítás nemcsak a kommunális infrastruktúra jelenlegi kiépítettségére igaz, hanem a háztartási- és elektronikai eszközökkel való ellátottság esetében is ugyanez mondható el. Ezért nem tekinthetó meglepő eredménynek, hogy a kérdőives felmérés alapján Jármiban a megkérdezettek mintegy $11 \%$-a, Ópályiban pedig egynegyede az elmúlt tíz évben költözött a településre a megyén belülröl, döntöen a közeli városból. A fentebbi tényezökön túl tovább erősítheti a folyamatot, hogy a jó közlekedési kapcsolatok miatt Mátészalka térségi szerepü intézményei is gyorsan elérhetök. A meglévõ munkahely megtartását sem veszélyezteti a kiköltözés, mivel a Jármiban élöknek átlagosan fél órát kell utazniuk naponta egy mátészalkai állás esetében, az ópályi lakosoknak pedig átlagosan alig 17 perc kell ahhoz, hogy beérjenek a városba (a mátészalkai átlagérték 39 perc, de ebbe bele kell érteni a távolsági ingázókat is, akik esetében ez az időtartam több órára is növekedhet). 
A lakásállományt és annak szerkezetét vizsgálva azt tapasztalhatjuk, hogy a város lakásainak száma hullámzó ütemben ugyan, de gyarapszik. 1990-ben 6228 lakás szerepelt a nyilvántartásban, és 139 lakás épült az év folyamán. 1994-re az értékek 6507-re illetve 28-ra módosultak, 1997-ben pedig 6740 volt a lakások száma, az újonnan épülteké pedig 60 . Ebben a tekintetben tehát úgy tủnik, a város már túljutott a rendszerváltás okozta hullámvölgyön, és ismét érzékelhetö fejlödést mutat. Ennek (és a népességcsökkenésnek) köszönhetöen a 100 lakásra jutó lakosok száma az 1990-es 304-röl 1997-re 270 före mérséklödött, vagyis a megyei átlagot meghaladó értékröl a megyei átlag alá csökkent (291 illetve 276 fö volt az érték a megfelelő években a megye egészét tekintve).

A lakások átlagos nagysága nem sokat változott, döntöen két- vagy háromszobás lakások épültek és épülnek. Az infrastrukturális ellátottság azonban örvendetesen növekszik az utóbbi tíz évben, és nemcsak a városban, hanem a környezö településeken is (az ivóvíz-ellátás kivételével szinte minden nagyobb beruházás erre az idöszakra esik a falvakban). A gázvezeték-hálózat hossza 69,6 km-röl 76,5 km-re bövült 1990 és 1997 között, a bekapcsolt fogyasztók aránya pedig 35\%-ról 65\%-ra emelkedett. A vezetékes ivóvíz-szolgáltatásba bekapcsolt lakások aránya 76,7\%-ról 90\%-ra; míg a szennyvízcsatorna-hálózatba bekötött lakások aránya 37,6\%-ról 66\%-ra növekedett a fent említett idöintervallumban. A burkolt belterületi utak aránya szintén folyamatosan emelkedik, 1994-ben 78,6\%, 1998-ban 81,4\% volt a részesedésük. A kommunális hulladék elhelyezése jelenleg még nem megoldott, de a tervek között szerepel egy korszerủ regionális hulladéklerakó megépitése, amely jelentösen enyhítene a természeti környezetet veszélyeztető problémán (1.ábra).

\section{1. ÁBRA \\ A kommunális infrastruktúra-hálózatokba bekapcsolt háztartások aránya Mátészalkán \\ (Ratio of Households Connected to the Communal Infrastructure Network in Mátészalka)}

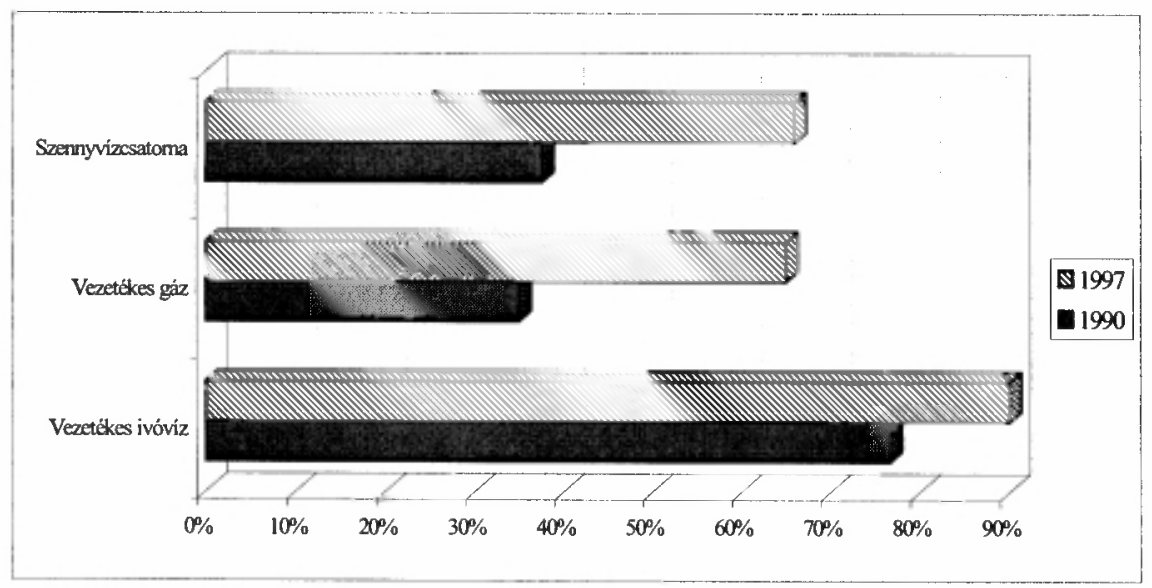

Forrás: KSH 1998. 
Az egészségügyi infrastruktúra a racionalizálási törekvés mellett töretlenül fejlödik: az 1996-ban befejezett kórház-rekonstrukció (modern laborokkal, diagnosztikai egységgel és sebészeti mütővel, valamint hotelszárnnyal bỏvült) után az intézmény csaknem teljes körü alapszolgáltatást és speciális szolgáltatásokat is nyújt a vonzáskörzetébe tartozó mintegy 88 ezer ember számára, a keleti országrész átlagánál magasabb színvonalon. A kórházi ágyak száma a kilencvenes évek közepén tapasztalt emelkedés után az országos trendnek megfelelỏen csökkent (1990-ben 414, 1997-ben 402 darab), a kihasználtság pedig az erőteljes csökkenés után ismét növekszik (1990: 82,7\%, 1994: 72,4\%, 1997: 73,6\%).

A városban négy középiskola müködik, és a pénzügyi okokból bekövetkezett leépítések, összevonások ellenére sikerként könyvelhetö el, hogy nem csökkent az oktatás színvonala (a Baross László Mezögazdasági Szakközép- és Szakmunkásképzö Iskola az ország élvonalába tartozik). Fokozatosan bỏvült a tantermek száma (1990: 47; 1997: 60). A szakmunkásképzés térvesztése ellenére a nappali tagozatos tanulók létszảma tartósan 3000 körül alakul. Ugyanakkor a kérdőíves vizsgálat tapasztalatai alapján a mátészalkaiak átlagos képzettségi szintje a legalacsonyabb a vizsgált öt alföldi város (Gyula, Kalocsa, Mátészalka, Szeged, Szolnok) között, vagyis a képzett szakemberek nagy része nem marad a városban.

$\mathrm{Az}$ idegenforgalom lehetőségeit tekintve hullámzó fogadóképesség a jellemzö. A rendszerváltás utáni óriási visszaesés után a kilencvenes évek közepétől megkezdödött a kereskedelmi szálláshelyek bővülése, de az 1990-es szintet még nem sikerült elérni sem ebben a tekintetben, sem az idelátogató vendégek számát nézve. 1990-ben 365 férőhelyen 7384 turista (ebből 2011 külföldi) összesen 37049 vendégéjszakát töltött a városban, 1994-ben viszont a 78 féröhelyen mindössze 868 vendéget (ebből 637 volt külföldi) regisztráltak, a vendégéjszakák száma pedig 2403-ra csökkent. 1997-re a férőhelyek száma 123-ra bővült, és az idelátogatók száma jelentősen emelkedett (1718 före, ebböl 294 fö volt a külföldi), és a vendégéjszakák tekintetében is ugyanez mondható el, miután 4917-re nött ez az érték. Érdemes figyelmet fordítani arra, hogy a rendszerváltás óta csaknem tizedére esett vissza a külföldiek száma, és az arányuk 27,2\%-ról 17,1\%-ra csökkent.

A város gazdasági életében szintén nagy változások zajlottak le az utóbbi tíz évben, föként a tulajdonformát és a foglalkoztatási szerkezetet tekintve. A korábban tisztán állami tulajdonú vállalatok helyett napjainkra itt is a magánvállalkozások, ezen belül döntően az egyéni vállalkozások túlsúlya lett jellemző. 1994-ben 111 jogi személyiségü (2 vállalat, 100 gazdasági társaság és 9 szövetkezet) és 144 jogi személyiség nélküli gazdasági szervezetet tartottak nyilván, az egyéni vállalkozások száma 1313 volt. 1997-re a jogi személyiségü gazdasági szervezetek száma már 178-ra emelkedett (9 vállalat, 155 gazdasági társaság, 7 szövetkezet), a jogi személyiség nélkülieké pedig 1162-re módosult, beleértve a számukat tekintve csökkenést mutató 983 egyéni vállalkozást is.

Az adatok tanúsága szerint az egyéni vállalkozások többsége a szolgáltatásban és a kereskedelem területén müködik. 1997 elején a müködő vállalkozások döntő többsége 
a szolgáltató szektorban müködött $(78,2 \%)$, ipari és épitőipari tevékenységet 18,7\%-uk folytatott, míg a mezőgazdasági vállalkozások aránya $3,1 \%$ volt (ez a szám kb. 3000 egyéni gazdálkodót takar). Jól alátámasztja ezt a következő adatsor; 1990ben 89 kiskereskedelmi üzlet volt a városban. 1994-re ezek száma 410-re emelkedett, majd - párhuzamosan az egyéni vállalkozások számában történt visszaeséssel - némi csökkenést követően 1997-ben 383-at regisztráltak. Hasonló bövülést figyelhetünk meg a vendéglátóhelyek esetében: 1990-ben mindössze 18 volt a városban, 1997-ben pedig már 96 ebben az üzletágban tevékenykedö vállalkozásról beszélhetünk. Jelentösen bővült a pénzügyi szolgáltatások köre is: 1997-ben 5 pénzintézet és 6 biztosítótársaság volt jelen a városban.

A mezögazdaság és az ipar tekintetében meglehetösen vegyes a kép az elmúlt éveket tekintve. A sikerek mellett számos probléma nehezíti a továbbfejlődést. 1990-ben még 34 telephelyen (ebböl 26 volt ipartelep) 4940 fö volt a foglalkoztatott munkaerö létszáma, 1994-re azonban a telepek száma 24-re csökkent, a foglalkoztatottak száma pedig 2644 före esett vissza. Ebben jelentös szerepet játszott a szocialista nagyvállalatok tönkremenetele mellett az egykori mezőgazdasági nagyüzemek csődje is. Ekkor jelentős mértékben megnôtt a munkanélküliség, egyes időszakokban $30 \%$ körüli szintig emelkedett. Csak a sikeres privatizáció jelenthetett kiutat az egyre nehezebbé váló helyzetböl, és a város ezen a téren kétségkivül jó eredményeket tudott felmutatni.

Sikerült - különösen a Carl Zeiss Hungária Optikai Kft. személyében - tőkeerős, fejlesztésekre képes, stabil nyugati piacokkal rendelkező cégeket bevonni a folyamatba. Ennek eredményeképpen 1997-ben a 23 ipari telepen már 3111 munkavállaló számára biztositottak álláslehetőséget (a fejlődés döntően a Zeissnek köszönhető, mivel a 300 fös induló létszám napjainkra 1000 fölé emelkedett). Az ezer före jutó ipari foglalkoztatottak száma így Mátészalkán 159 före emelkedett, ami megyei viszonylatban is magasnak számít, csupán Kisvárdán magasabb ez az érték.

Igen sokat árulnak el Mátészalka valós gazdasági-társadalmi helyzetéről és súlyáról annak az összesített rangsorrend-vizsgálatnak az eredményei, amelyek 13 kiválasztott fontosabb statisztikai mutató értékein alapuló számításokból születtek. A KSH, illetöleg a Tstar 1994. és 1997. évi adatbázis segítségével, az ún. rangszámítás módszerével elvégzett értékelés nemcsak a kialakult helyzetet, hanem az 1994 1997 közötti elmozdulást is jól tükrözi. Igaz ugyan, hogy az összesített átlagok szerint három év alatt valamelyest romlott Mátészalkának az országos rangsorban elfoglalt pozíciója, miután a több mint 3100 település sorában a 646. helyröl a 694-re „csúszott vissza" a város, a gazdasági fejlettség szintjét jellemző egyes mutatókat tekintve azonban már lényegesen kedvezöbb kép rajzolódik ki (1. táblázat). A munkanélküliek, a gépkocsik, a lakásépítések, az egyéni vállalkozások, a jogi személyiségú gazdasági szervezetek és a kiskereskedelmi boltok 1000 före számított arányát tekintve ugyanis Mátészalka jelentős mértékben javította pozícióját a települések országos rangsorában. 
Az egyéb mutatókat illetỏen sem túlzottan rossz a város helyzete, eltekintve a már jelzett, „speciálisan” szabolcs-szatmári demográfiai jelenség, különösen a vándorlási különbözet kedvezőtlen alakulásától. Nehezen magyarázható a természetes szaporodás jelentős visszaesése is. Jóllehet Mátészalka nem került be ugyan a legjobb pozíciójú 625 település közé, attól kissé elmarad, de összességében a város helyzete így is kedvezỏnek tekinthetö.

\section{TÁBLÁZAT}

Mátészalka pozíciója és annak változása a települések országos sorrendjében a rangszámitás módszerével készült 13 fontosabb mutató összesitett értéke alapján (The Position and Change of Mátészalka in the Order of the Settlements in Hungary by the Methodology of Rank Computation based on the Aggregated Value of the 13 Main Indicators)

\begin{tabular}{lrrr}
\hline \multirow{1}{*}{\multicolumn{1}{c}{ Mutató neve }} & \multicolumn{2}{c}{$\begin{array}{c}\text { Mátészalka helye } \\
\text { a települések országos } \\
\text { sorrendjében }\end{array}$} & $\begin{array}{c}\text { Változás } \\
1994-1997\end{array}$ \\
\cline { 2 - 3 } & 1994 & 1997 & \\
\hline 1. Lakónépesség & 68 & 71 & -3 \\
2. Természetes szaporodás & 636 & 951 & -315 \\
3. Vándorlási különbözet & 2079 & 2633 & -554 \\
4. Munkanélküliek aránya & 2054 & 1777 & 277 \\
5. Gépkocsik aránya & 334 & 142 & 192 \\
6. Telefonok aránya & 139 & 371 & -232 \\
7. Lakásépítés & 1264 & 1071 & 193 \\
8. Csatornázottság & 113 & 234 & -121 \\
9. Egy adófizetöre eső nettó jövedelem & 254 & 315 & -61 \\
10. Egyéni vállalkozások aránya & 439 & 400 & 39 \\
11. Jogi sz. gazdasági szervezetek & 527 & 465 & 62 \\
12. Általános iskolai tanulók aránya & 318 & 444 & -126 \\
13. Kiskereskedelmi boltok aránya & 168 & 144 & 24 \\
Átlagosan & 646 & 694 & -48 \\
\hline
\end{tabular}

Forrás: KSH. Készültt dr. Csordás László számításai alapján.

Az 1990-es évek végére az egész magyar önkormányzati rendszerre hatalmas súllyal nehezedő pénzügyi gondok elöl azonban ez a város sem bújhatott el, és a régióban található legtöbb településhez hasonlóan az önhibáján kívül nehéz helyzetben lévő önkormányzatok népes táborához tartozik már évek óta. Ez azt jelenti, hogy külső segítség nélkül nem tudja megőrizni a mủködési egyensúlyt, illetve nem képes ellátni a számára kötelezően elöírt feladatokat (intézmények múködtetése stb.) sem. Emiatt 1999-ben Mátészalka és térsége települései 227 millió forintos „önhikis” pályázatot nyújtottak be a kormányzathoz, és az elörejelzések szerint erre rákényszerülnek majd az elkövetkezö években is. Mindez azt jelenti, hogy a város továbbra sem vállalhat plusz feladatokat, és a saját erőből történő fejlesztések lehetőségei szintén erősen korlátozottak. 


\section{Mátészalka „holdudvara”: Ópályi és Jármi}

Mátészalka agglomerációs övezetébe tartozó, attól északi irányban mindössze 3 km-re fekvő, a „magasan fejlett községek” csoportjába sorolt Ópályi a Szatmárisíkságon (a Nyírség és az Ecsedi-láp határán), Nyíregyházától kissé ÉK-re, a Kraszna partján található. Közlekedés-földrajzi helyzete viszonylag jónak mondható, területén áthalad a Mátészalka-Záhony vasútvonal, és közúton is jól megközelíthető a 49-es útról Mátészalkánál leágazó alsóbbrendủ úton. A falu neve elöször 1294-ben tünik fel okleveleinkben, és a következỏ évszázadokban meglehetösen viharos a története. Hovatartozása is többször változott: a XV. századtól általában Szabolcs vármegyéhez sorolták, de az 1500-as évek elejétöl a XVII. század végéig a szatmári várhoz tartozott. A pusztítások miatt többször került sor jelentős szláv népelem betelepítésére (a XVI. és a XIX. században). 1856-ban egy hatalmas tüzvész során a református templom kivételével gyakorlatilag az egész település megsemmisült, de az 1911-13-as névtárak szerint már újból 1972 lakosa volt.

A község népességszáma több évtizedre visszamenöleg folyamatosan emelkedik, és ez szinte kizárólag a természetes szaporodás pozitívumának (a születések száma meghaladja a halálozásokét) köszönhető, a ki- és beköltözések száma megközelítöleg azonos. 1990-ben 2851, 1997-ben pedig 3038 fỏ volt a falu lakónépessége. A korcsoportonkénti megoszlást tekintve a településen magas (26\%) a fiatalok aránya, és ez - valamint a természetes szaporulat - leginkább a roma etnikum magasabb arányával hozható összefüggésbe. Nagyrészt az utóbbiak miatt nem vált Ópályi Mátészalka alvótelepülésévé.

Az elmúlt néhány évben igen jelentös infrastrukturális beruházások történtek, melyek során csaknem 100\%-osan kiépült a villany-, víz-, gáz- és csatornahálózat, illetve valamennyi belterületi utat burkolttá tették. Az európai színvonalhoz mérhető évtizedes lemaradásokat azonban sem itt, sem Jármiban nem sikerült ilyen rövid idő alatt pótolni, ahogyan az a hálózatokra csatlakozó lakóházak arányából is kitủnik. 1997-ben a 853 darab lakás 65\%-a volt ellátva vezetékes ivóvízzel, 85\%-a vezetékes gázzal és $65 \%$-a telefonnal, a szennyvízcsatorna-hálózatba pedig $25 \%$ volt bekötve (2. ábra). A település rendelkezik óvodával és általános iskolával, valamint itt található a mátészalkai Baross László Mezőgazdasági Szakközépiskola egyik gyakorlótelepe és gazdasága.

Ópályi mezögazdasági település, ipara egyáltalán nincs. Ezért nehezedett óriási súllyal a falura a földtulajdon rendezetlensége a Mátészalkával és Kocsorddal közös termelöszövetkezet felbomlása után (az ügy végére csak 1999-ben került pont), mivel a magas munkanélküliséget csak a ma még igen gyér mezőgazdasági vállalkozások szoríthatják vissza elviselhetőbb szintre. A településen 1997-ben 15 társas és 107 egyéni vállalkozás mủködött, a kiskereskedelmi boltok száma 19, a vendéglátóhelyek száma pedig 8 volt. 


\section{2. ÁBRA}

A kommunális infrastruktúra-hálózatba bekapcsolt háztartások aránya a vizsgált településeken 1997-ben

(Ratio of Housholds Connected to the Communal Infrastructure Network in the Examined Settlements in 1997)

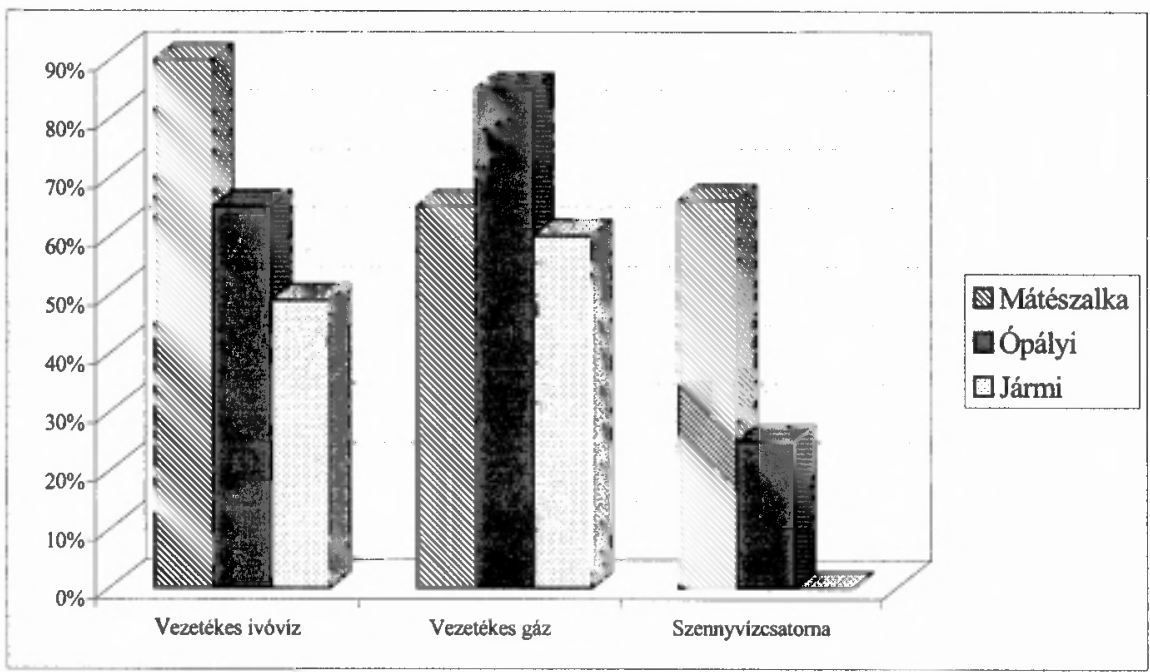

Forrás: KSH 1998.

A vizsgálat céljaira Mátészalka környezetéból kiválasztott másik falu, Jármi az ÉK-Nyírségben, a megyeszékhelytől mintegy $52 \mathrm{~km}$-re keletre, Mátészalkától pedig csupán $5 \mathrm{~km}$ távolságban nyugatra fekvö, eredetileg két út találkozásánál kialakult település. Közlekedési helyzete kielégitő: vasútvonala nincs, de közúton a 49-es út révén könnyen elérhető. Első említésekor (1325-ben) még Járomtelke néven szerepelt, és a Karásziak birtokaként tüntetik fel. Később az akkor még két településböl álló Mátészalka része lett, majd többszöri birtokosváltást és óriási pusztításokat ért meg. Mátészalkához hasonlóan 1701-re gyakorlatilag elnéptelenedett, és 1716-ban is mindössze 3 zsellér és egy özvegy élt az akkori „faluban”. Ezután azonban 700 fö környékén állandósította népességét: 1870-ben 733-an lakták, az 1911-13. évi névtárak alapján pedig 702 fö volt a lakosok száma.

A népesedési folyamatok azóta kedvezöbbekké váltak. A település 1970 óta lassan, de biztosan növeli lakosainak számát (1990-ben 1186, 1997-ben pedig 1214 fö volt a lakónépesség). A természetes szaporulat Ópályihoz hasonlóan magas (a születések száma megközelítően kétszeresen múlja felül a halálozásokét), és a népesség korcsoportos megoszlása ugyancsak kedvezönek mondható. Különbség mutatkozik viszont a migráció tekintetében, mivel itt a kitelepülók száma meghaladja a beköltözőkét, vagyis Mátészalkához hasonlóan negatív a vándorlási különbözet.

Az infrastruktúra általános fejlettségi szintje közepesnek minösithetö, 1997-ben nem érte el az Ópályiban megfigyelhető kiépítettséget. Különösen igaz ez a vízmüellátottság területén, mivel a vezetékes ivóvíz-szolgáltatásba a 459 darab lakás 
mindössze 49\%-a volt bekapcsolva, a szennyvízhálózat pedig még nem épült ki. Jobb volt a helyzet a vezetékes gázzal és a telefonnal való ellátottság területén, mivel itt 60 illetve 59\%-os értékeket figyelhettünk meg. A belterületi utak itt is teljes mértékben burkoltak. A közintézményekkel való ellátottságra nem lehet panasz. Az 1997-es esztendőben kezdődött meg a tanuszoda építése (azóta már átadták), továbbá a lakók rendelkezésre áll egy óvoda, egy általános iskola, egy könyvtár és egy müvelődési ház is.

A település lélekszámához viszonyítva magas a gazdasági társaságok száma, és tevékenységi körük összetettebb, mint az Ópályiban múködö vállalkozásoké. A 7 kft. és 2 bt. mellett 39 egyéni vállalkozás müködött a településen 1997-ben. Legtöbbjük (szám szerint 18) itt is kereskedelmi tevékenységet folytatott, 10 volt a mezőgazdasági vállalkozások száma, 9 folytatott szolgáltató tevékenységet, míg 2 ipari jellegủ volt. A faluban ebben az évben 21 kiskereskedelmi bolt müködött, és 6 vendéglátó egység valamint egy melegkonyhás üzlet állt a lakosság és az idelátogatók rendelkezésére. A némileg összetettebb gazdasági élet ellenére Ópályihoz hasonlóan a munkanélküliségi ráta szintén a Mátészalka térségében ez idő tájt tapasztalható $22 \%$-os szint körül mozgott, bár néhány százalékponttal alatta maradt.

A Mátészalkára és a közvetlen környezetére az utóbbi évtizedben jellemző fejlödés tehát nem volt töretlen, és nem mentes az ellentmondásoktól sem. Az ország gazdasági-társadalmi és politikai változásai ezt a térséget sem kerülték el, és az átalakulás viharai és nehézségei az eredmények mellett sok ember életében jelentettek olyan törést, amelynek következtében nem feltétlenül látják sikeresnek városukat. A fejlődés, a sikeresség kérdésének megitélése azonban nemcsak a „kisemberek" esetében ellentmondásos, hanem - ahogyan az a kérdöíves felmérés elemzéséböl és az elkészitett interjúkból utóbb kiderül - általában véve a térség lakossága és minden társadalmi rétege többségét illetően is.

\section{Vélemények egyetlen kérdésről-tanulságos interjúk tanúságai}

A kutatás keretében végzett kérdőives felmérés alapján a három településen eléggé megosztott a lakosság abban a tekintetben, hogy valóban tapasztalható-e érdemi, a számukra is érzékelhető fejlödés. Hasonló tapasztalatok születtek a kérdöives felméréshez kapcsolódó személyes interjúk felvétele során is. Az interjúalanyok, polgármesterek, a közélet és a gazdasági-társadalmi élet képviselői szinte kivétel nélkül megfogalmaztak néhány komoly kételyt ezzel a kérdéssel kapcsolatban. Különösen igaz ez Mátészalka esetében, ahol a megkérdezettek általában ugyan látnak fejlödést, de úgy érzik, hogy az elörehaladásnak nem megfelelö az üteme, illetve a város nem feltétlenül azokon a területeken fejlödik, ahol arra a leginkább szükség lenne (3. ábra).

Meglehetösen heterogén az önkormányzati testület munkájának megitélése. Abban mindenki egyetértett, hogy a településen tradicionálisan (politikai rendszertől függetlenül) aktív, a városért tenni akaró és tenni is tudó városvezetés múködött. Arról azonban már megoszlanak a vélemények, hogy a település ennek köszönheti-e 
leginkább a sikereit, és hogy mindenkor kihasználták-e a városban és környezetében rejlö adottságokat. Nem volt egyetértés abban a tekintetben sem, hogy a lakosság érzékeli-e a település fejlödését, és hogy a települési és a természeti környezet a helyiek számára valóban a mindennapokban tapasztalhatóan előnyös irányba változott volna. A megkérdezettek véleménye szerint (kivéve az önkormányzati tisztviselöket) a város fejlödését igazából csak egy szükebb réteg érzékeli és ismeri el; a többség azonban közömbös, vagy kissé talán elégedetlen is.

A sikeresség megítélésének alapvetöen két oka van: egyrészt a sikerességet nehezebb észrevenni, mint a kudarcokat, és a sikerekhez hozzászokva az emberek elöbb-utóbb ezt az állapotot tekintik természetesnek. Ilyen körülmények közepette pedig sokkal nehezebb eredményeket felmutatni. Másrészt az újbóli várossá nyilvánitás (vagyis 1969) és a rendszerváltás közötti idöszakban viharos fejlödésen ment keresztül az élet minden terïletén (életkörülmények, munkalehetőségek), és a megye leggyorsabban fejlődő városa címért volt versenyben a megyeszékhellyel. A lakosság ma is - Nyíregyháza mögött - a megye legdinamikusabban fejlődỏ telepuilésének tartja a sajátját, de a megyeszékhely és Mátészalka között fényévnyire növekedett távolságot az 1989. esztendö után lelassult, megtorpant fejlödéssel magyarázza. Ezt a sikerességet már korántsem érzik olyan volumenünek, mint amilyenhez a korábbi évtizedekben hozzászoktak, és emellett számos, korábban ismeretlen negatív tényezővel (leépítések, munkanélküliség stb.) is szembe kellett nézniük. A munkájukat vesztett, a mindennapi megélhetés gondjával küzdő, a társadalom peremére került emberek pedig egészen biztosan nem érzékelnek fejlödést, hiszen nem a közösség eredményeiből, hanem a saját helyzetük alakulásából indulnak ki.

\section{3. ÁBRA}

A települések fejlödésének lakossági megitélése a rendszerváltástól napjainkig (Public Judgement of the Development of the Settlements from the Change of the System to Recent)

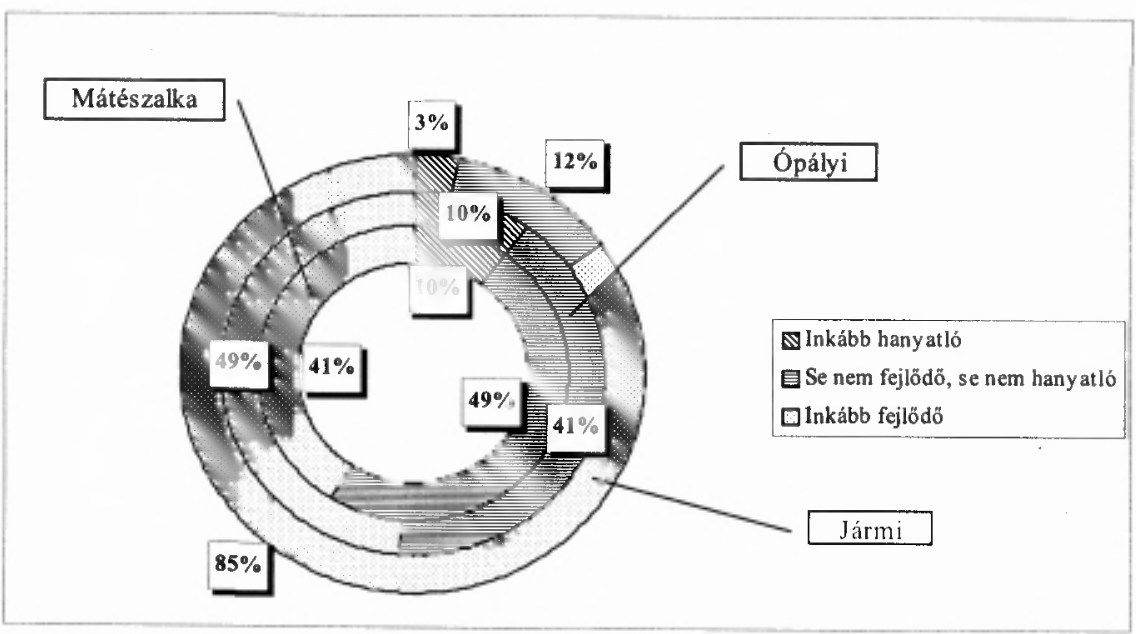

Forrás: KSH 1998. 
Mátészalka önkormányzati vezetői - mint a település pénzügyi és egyéb lehetőségeinek legjobb ismerői - az utóbbi tíz évet sikeresnek minősítették, bár korántsem nevezhetők mindennel elégedettnek. A legfontosabb sikernek azt tartják, hogy a romló pénzügyi feltételek ellenére sikerült fenntartani az intézményhálózat müködését, és mindez nem járt a város gazdálkodási egyensúlyának megbomlásával. Ugyanakkor tudatában vannak annak is, hogy nem mindenben tudtak megfelelni a valós lehetőségeket nem ismerő lakosság sokszor túlzó, illuzórikus igényeinek. A munkájukkal szembeni elégedetlenség legfőbb okát abban látják, hogy kényszerüségből számos területen jelentősen csökkenteniük kellett a szerepvállalásukat (például az önkormányzati bérlakások fenntartása), illetve a szükös keretek miatt képtelenek a lakosság által elvárt ütemben fejleszteni a várost. A sikeresség egyik alapja viszont éppen az volt, hogy nem vállalták túl magukat - és a város mủködöképessége érdekében ezen a szélsőségeket kerülő politikán az elégedetlen hangok ellenére sem kívánnak változtatni.

Nem alakult ki egységes' álláspont a helyi társadalom szervezettségének és aktivitásának megitélésében sem, sőt kifejezetten széles skálán mozogtak a vélemények. Általánosságban azonban elmondható, hogy a válaszadók ebben a tekintetben sem voltak elégedettek. A legtöbben azt emelték ki, hogy az emberek nagy része mára közömbössé vált a város jelenét és jövöjét illetően. Annak ellenére is így gondolják, hogy egy-egy közös cél érdekében (köztéri szobrok felállítása stb.) meg lehet mozgatni öket, és szép számú civil szervezet (Rotary Club, Nőegylet, KocsisHauser Alapítvány, Munkaadók Szövetsége stb.), valamint nyolc müvészeti csoport müködik a városban. Az utóbbiakról azonban megjegyezték, hogy mivel nagyon fiatalok, ezért még nem fejthetik ki igazán széles körben a tevékenységüket, és $m a$ még nem tudnak kellö hatásfokkal tevékenykedni a lakosság aktivizálása érdekében.

Sokak véleménye szerint a város sikerességének egyik fontos tényezöje éppen az a fajta lakossági szemlélet volt, amelyik sem magától, sem a városvezetéstöl nem türte el $a$ hosszabb távú egy helyben toporgást. Való igaz, hogy az emberek döntő többsége a saját problémáival van elfoglalva, de azt is figyelembe kell venni, hogy napjainkban éppen emiatt a fentebb felsoroltak az átlagosnál magasabb fokú lakossági aktivitást jeleznek; és Mátészalka iskolaváros jellegéből adódóan különösen a kultúra területén érezhető valamiféle fiatalos lendület, tenni akarás.

A mátészalkai interjúalanyok mindegyike egyetértett azonban azzal, hogy a vonalas és a humán infrastruktúra, az oktatás, a müvelödési lehetöségek és a közbiztonság területén jelentösen fejlödött Mátészalka az utóbbi tíz évben. Más kérdés, hogy ezt mennyire tartják elégségesnek a jövő szempontjából. Néhányan úgy érzik, hogy az infrastrukturális beruházások, a költséges iskolafenntartás helyett inkább munkahelyteremtésre kellett volna fordítani a rendelkezésre álló amúgy sem bőséges tökét. A legfontosabb érv emellett az, hogy a városban igen magas a munkanélküliség, és ez egyrészt a társadalom egyre szélesebb rétegeiben általánosan tapasztalható elszegényedéshez vezet, másrészt csökkenti a helyben keletkező tőkét (helyi 
adók stb.), és a tartós állástalanság egyre értéktelenebbé teszi a rendelkezésre álló munkaeröt.

Mások ugyanakkor azt hangoztatják, hogy az infrastruktúra kiépítettsége még egyetlen településnek sem ártott, és jelentősen javít a helyiek életkörülményein, ezen keresztül az általános hangulatán is. Másfelöl többek között éppen a kiépített ipari park miatt települtek ide a jelenlévő külföldi cégek, tehát a beruházások mégiscsak megtérültek. Azt is figyelembe kell venni, hogy sem a szinte folyamatosan forráshiányos önkormányzat, sem a tökeszegény helyi vállalkozók nem képesek öneröből nagyobb fejlesztésre (gyakorlatilag csak a Zeiss mondhatja ezt el magáról), a kisebb bővítések pedig nem érzékelhetők a többség számára.

Talán már nem jelent különösebb meglepetést, hogy a város és környéke viszonyának, valamint Mátészalka környezetére gyakorolt, a sikerességet továbbadó kisugárzó hatásának megitélését sem lehet a homogén jelzövel illetni. Három fö csoportra oszthatjuk a véleményeket: az elsö szerint a kisugárzó hatás erös, a település viszonylag jó viszonyban van a szomszédos falvakkal, és a kisebb nehézségek ellenére létezik az együttmüködés. Ez leginkább az infrastruktúra fejlesztésében érhetö tetten: a legtöbb település a kiépitett mátészalkai hálózatokra kapcsolódott rá, és ez az alap jelentös mértékben segítette a saját rendszerek megvalósítását. Emellett a város kisugárzó ereje a közintézmény-hálózatból is adódik, mivel ezek az intézmények (föleg az iskolák és a kórház) sokat segítenek a térség lakosainak, és megkímélik őket a megyeszékhelyre való utazás nehézségeitől. Sajnos ez a vélemény jelenti a kisebbségi álláspontot, leginkább a mátészalkai képviselőtestület véleményét tükrözi.

A másik, az elöbbivel homlokegyenest ellentétes álláspontot hangoztató véleménycsokor szerint a város és környezetének kapcsolata - finoman szólva sem felhötlen; és Mátészalka csak önmagában sikeres, nem generál fejlödést maga körül, sớt a legtöbb esetben inkább hátráltatja azt. Ezt a véleményt a városon kívül, a két érintett községben megkérdezett vezetöktől hallottuk, akik természetesen egészen más szemszögbőll látják a települések közötti kapcsolatrendszert és Mátészalka térségszervezö szerepét. Mindkét településen elismerték, hogy a város sikeressége bizonyos területeken rájuk is pozitív hatást gyakorol (infrastruktúra, közintézmények, munkalehetőségek). Mégis úgy érzik, hogy a településeken saját erőböl, a nagyobb szomszéd segítsége nélkül valósították meg a beruházásokat, és azok nem a város kisugárzó erejéből származnak (Jármiban egyenesen úgy érzik: tulajdonképpen ők nevezhetők igazán sikeresnek az elmúlt tíz évben és nem a térségi központ).

Ennek megfelelően úgy látják, hogy Mátészalka nem tud a térség igazi dinamizáló központjává válni (csak a meglévö szerepkörét és elönyeit örzi); és nem kezdeményezi, hanem inkább akadályozza a szomszédos települések és a város összefogását. Ennek igazolására elmondták, hogy nagyon kevés a térségi programok száma - föleg azoké, amelyeknek Mátészalka állna az élén. Emellett Ópályi több területen is pereskedett a várossal: a közös tsz felbomlása körüli földterületi vita 
miatt csak 1999-ben zajlott le a földosztás (jelentösen hátráltatva a település fejlödését), és hasonló problémák merültek fel a gáz- és csatornahálózat-beruházásokkal kapcsolatban, mintegy 30 millió forintos nagyságrendben.

A vélemények szempontjából a harmadik álláspont kisebb-nagyobb eltolódásokkal valahol "félúton" helyezkedik el a két szélsöség között. Meglátásuk szerint a települések közti viszony valóban nem ideális, és böven van mit javítani rajta - de nem tér el jelentősen az ország egyéb területein tapasztalható átlagtól, és a város erejéhez mérten segítette és segíti a környezö falvak fejlödését is. Azt valamennyien elismerték, hogy a térségi szemlélet, a közös gondolkodás idönként eléggé gyenge lábakon áll. Abban a tekintetben azonban már megoszlottak a vélemények, hogy ezért ki okolható elsősorban. Az egyik álláspont szerint alapvetően Mátészalka az, aki javíthatna a jelenlegi viszonyokon, mivel ö az erösebb, és ő rendelkezik leginkább az ehhez szükséges eszközökkel. Éppen ezért a városnak kötelessége a lehető legeredményesebben összefogni a saját térségét, mert ez előfeltétele a további fejlödésnek.

Más szempontú az a megközelités, amely szerint ",mindkét fél" felelös a kialakult helyzetért, de a változások érdekében a környezö településeknek is többet kellene tenniük. A legalapvetöbb gondnak az az általánosan tapasztalható jelenség bizonyul, miszerint az önkormányzatok önállóságuk védelmében idegenkednek minden közös programtól. Ehhez hozzájárul az is, hogy a kisebb önkormányzatok úgy érzik: Mátészalka térségi érdekekre hivatkozva rátelepszik a forrásokra, elszivja elölük a levegôt. A városnak bizonyos értelemben valóban elönyös a helyzete (térségi méretüre fejlesztheti saját intézményeit, illetve azokból minél többet fenntarthat), de ez rengeteg költséggel jár együtt, amit szinte kizárólag a saját költségvetéséből kénytelen fedezni. A fejlesztések tehát nem öncélúak, ezt azonban fontos lenne megértetni és elfogadtatni a többi településsel is, mivel ezekböl ök szintén sokat profitálhatnak (más kérdés, hogy a hangvételen sokat kell még változtatni az eredmény érdekében).

\section{A sikeresség esélyei a perifériahelyzetben}

Az elózöekben volt már szó arról, hogy Mátészalka és környékének jelenét, sikerességét és annak tényezöit tekintve igen erös a véleménykülönbség a megkérdezett interjúalanyok körében. Ám a továbbfejlödés esélyeit firtató kérdésre egybehangzó volt a válasz: a városnak nagyon jók a dinamizálódási esélyei a következö évezredben, és megvannak az adottságai ahhoz, hogy a jövöben még dinamikusabban fejlödhessen.

Ahhoz, hogy kialakíthassuk saját véleményünket, sorba kell venni azokat az adottságokat és ugyanakkor azokat a gátló tényezóket is, amelyeken mindenképpen túl kell lépni a tényleges siker érdekében. Az adottságok között első helyen kell említeni Mátészalka földrajzi fekvését, mert ennek révén képes lehet arra, hogy eredményesen fogja össze a térség településeit. A kiépitett vasúti és közúti hálózat 
lehetővé teszi a város és intézményei, az északkelet-alföldi viszonyokhoz képest gyorsnak mondható elérhetöségét a környezö településekröl. Így Mátészalka ténylegesen eleget tud tenni közigazgatási-gazdasági és kulturális decentrum szerepének. Mindenképpen sikerként kell elkönyvelni, hogy a város fenn tudta tartani az ehhez szükséges intézményhálózatot; és a térség jövőbeni fejlődését meghatározza az, hogy sikerül-e továbbra is megtartani, esetleg bövíteni a központi funkciókat. Ezt jelentősen megnehezíthetik a szükös anyagi lehetöségek, mivel a térségszervező szerepkör megtartása sokszor eddig is csak az önkormányzati vagyoneladások árán volt lehetséges, a további értékesítések esélyei pedig egyre inkább csökkennek. Az ezekböl származó plusz bevételek hiányában pedig nem képzelhető el semmilyen nagyobb fejlesztés a jelenleg stabilnak tekinthetö (ugyanakkor rendkívül kihegyezett és emiatt könnyen sebezhetö) gazdálkodási egyensúly komolyabb felborítása nélkül.

A város intézményei által biztosított szolgáltatások minél széleskörübbé tétele (vagy legalább a jelenlegi szint fenntartása) azért különösen fontos, mert a város fekvése nagyon elönyös a kistérségen belül, ám regionális és országos viszonylatban ezt már korántsem mondhatjuk el. Mátészalka és közvetlen környéke az Északkelet-Alföld határ menti, perifériahelyzetben lévö, halmozottan hátrányos helyzetü térségének peremén fekszik, és emiatt számos nehézséggel kell szembenéznie. Ezek közül a legfontosabb az ország egyéb területeiröl való nagyon rossz elérhetöség, illetve a közlekedési vonalak szük áteresztőképessége. Fentebb már történt utalás arra, hogy Mátészalka jelentós vasúti csomópont, mivel öt vasútvonal fut össze a területén. Ugyanakkor viszont a kedvezö összképet alaposan lerontja az, hogy a megyeszékhelytől mérhető átlagos vasúti elérhetőség a térségi centrum esetében mintegy 90-120 perces utazási időt jelent. A határ menti települések vonatkozásában még ennél is rosszabb a helyzet, mivel esetenként 180 perc fölé emelkedhet ez a mutató. Valamivel kedvezőbbé válnak az értékek, ha a legrövidebb elérhetőséget vesszük figyelembe, ám ebben a tekintetben sem nevezhető ideálisnak a jelenlegi helyzet (4-5. ábra).

További negatívumként említhető az alábbi ábrákon is élesen kirajzolódó tény, hogy az egyes vasútvonalak között fekvő nagy kiterjedésủ területeken számos település fekszik teljes forgalmi árnyékban, és Mátészalka viszonylag kedvezőbb helyzete csak szigetszerü jelenség - bár éppen ezért messze kiemelkedik a távolabbi környezetéből. Jelentősen javíthatna a csöppet sem rózsás viszonyokon, ha a közúthálózat segítségével ezek a hátrányos helyzetü települések is gyorsan megközelíthetővé válnának, de sajnos jelenleg igen távol állunk ettől (6. ábra).

Mátészalka elérhetősége a megyeszékhelyröl közúton ugyan 60 perc alá csökken, de a határ menti sáv településeinek esetében az utazáshoz szükséges idő még ideális esetben is 90 perc környékén mozog, és a várostól távolodva gyors ütemben nő az érték. 

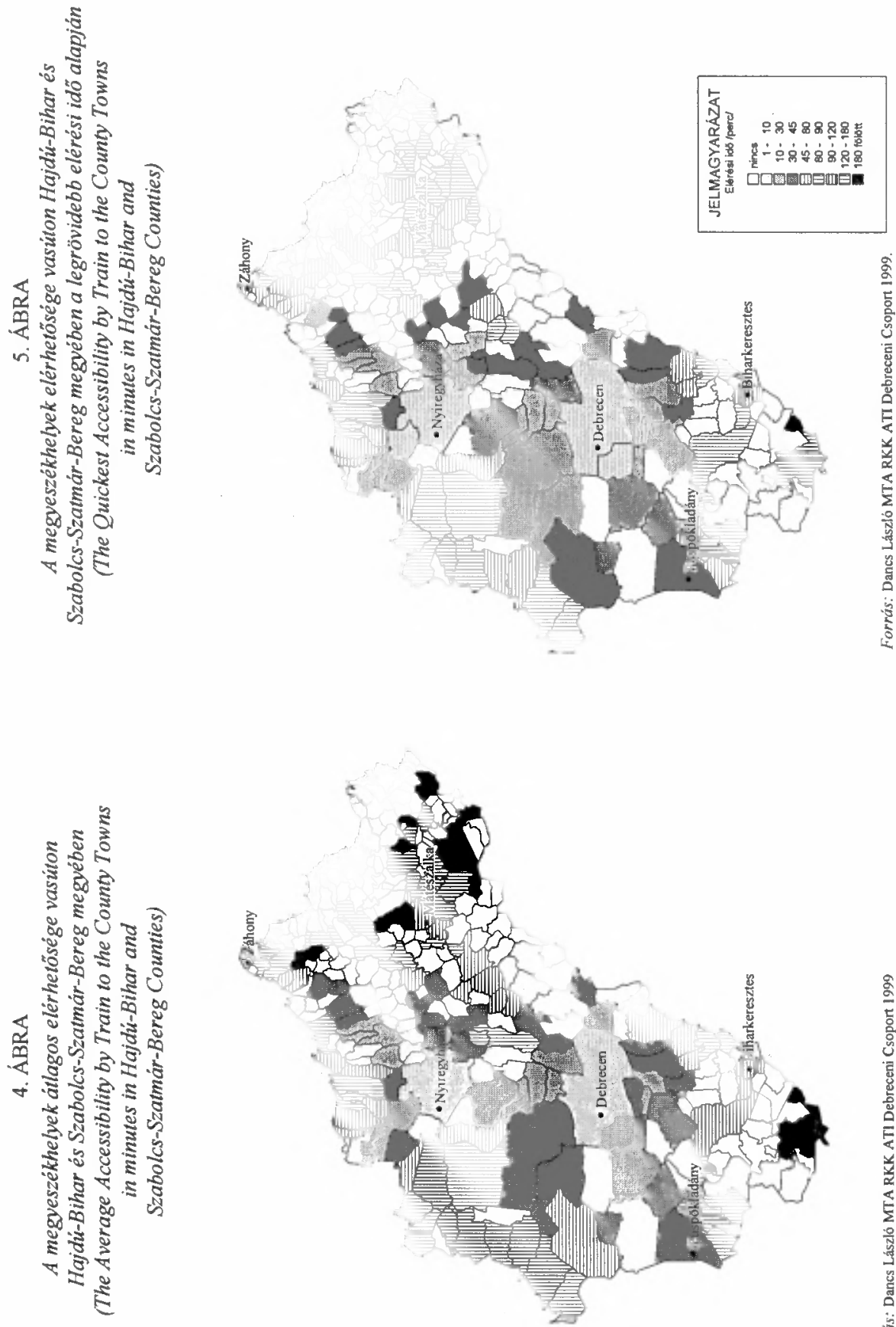
Baranyi Béla - Balcsók István:

Mátészalka, a sikeres város - igazi siker-e vagy csak reménytkeltö kitörési kísérlet?

Tér és Társadalom, 14. 2000. 1. 101-128. p.

\section{ABRA}

A megyeszékhely elérhetősége közúton a megye településeiröl

Hajdú-Bihar és Szabolcs-Szatmár-Bereg megyében

(The Accessibility by Car to the County Towns in minutes

in Hajdu-Bihar and Szabolcs-Szatmár-Bereg Counties)

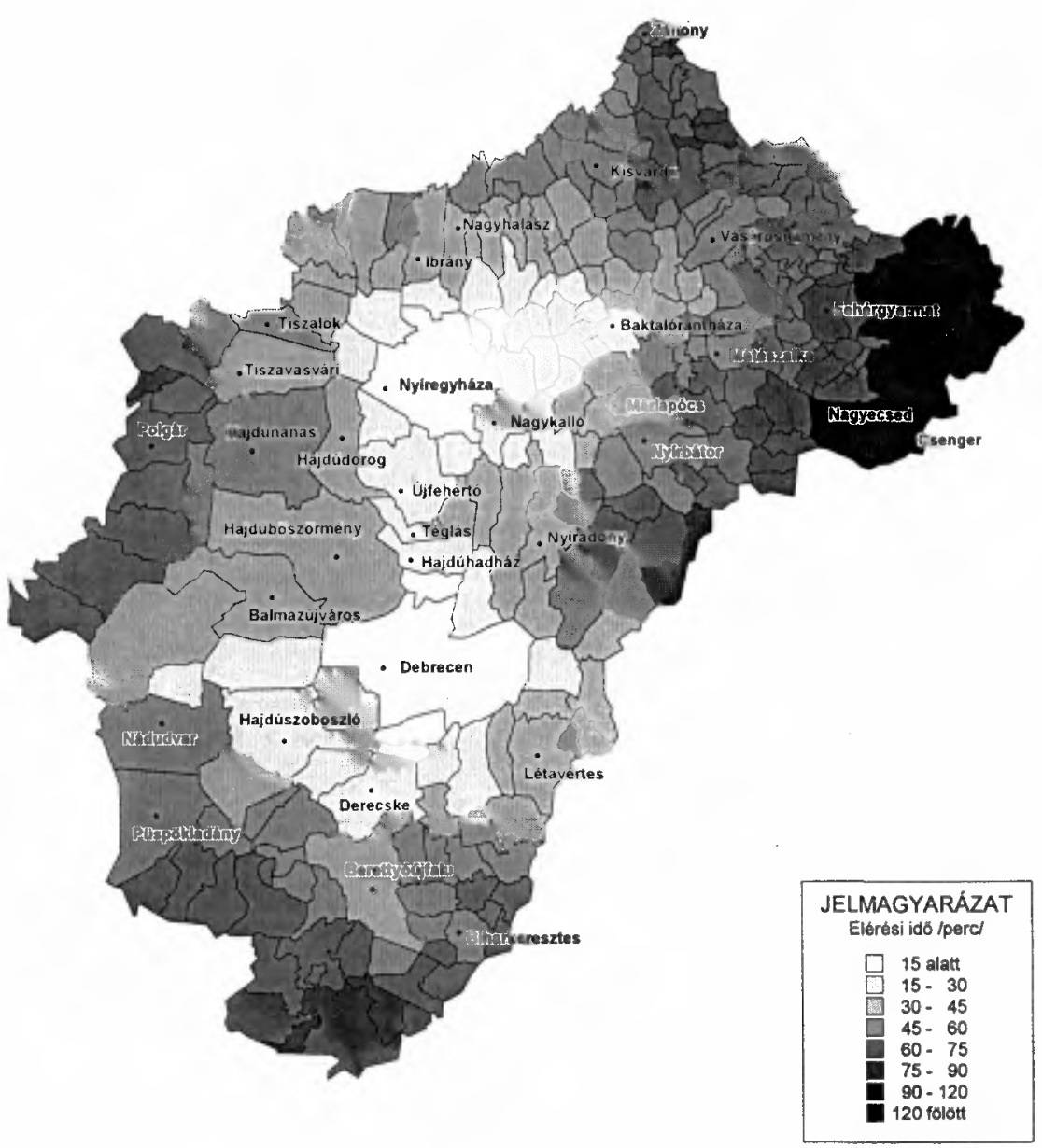

Forrás: Terra Studio Kft. - Dancs László MTA RKK ATI Debreceni Csoport 1999 
A napjainkra kialakult helyzetnek számos oka van (az úthálózat kiépítetlensége vagy hiányossága, illetve a meglévő hálózatnak a közlekedésre esetenként alkalmatlan állapota), amelyeket csak jelentős anyagi ráfordítással lehet orvosolni, és a térség jövőbeni fejlődésére mindenképpen hatással lesz, hogy az elmaradások pótlására nem elegendỏ egy-két év. Tovább rontja a térségben élök helyzetét, hogy az ingázás visszaszorulásával párhuzamosan a MÁV és a Volán számos járatot megszüntetett (bár nagy eredménynek tekinthetö, hogy nem szüntették meg a szárnyvonalakat).

Jelentősen javíthatna a jelenlegi kedvezỏtlen viszonyokon, ha minél hamarabb megépuilne az M3-as autópálya határig tartó szakasza - lehetöleg a városhoz minél közelebbi nyomvonalon. El kell kerülni azonban azt, hogy mindezt a lakosság fizesse meg a későbbi útdíjakon keresztül. Ez nem tenné kifejezetten vonzóvá az országrészt a nyugati befektetök szemében, a helyi lakosok többsége pedig nem elég gazdag ahhoz, hogy ténylegesen élvezhesse az új autópályák elönyeit. Ezért az országosan egységes használati dij helyett mindenképpen célszerü lenne egy, a helyi jövedelmekhez alkalmazkodó tarifarendszer kidolgozása, esetleg az itteni települések lakosaira vonatkozó „térségi autópálya-bérlet” bevezetése. Nem szabad megfeledkeznünk arról sem, hogy a majdan az M3-ashoz csatlakozó utak minősége sok esetben kritikán aluli, tehát az autópályával párhuzamosan ezeket is korszerúsíteni kell ahhoz, hogy a beruházások meghozzák a kívánt eredményt.

Mint az elérhetőségi viszonyokat szemléltetỏ ábrák jelzik, Mátészalka vonzáskörzetében számos település fekszik ún. forgalmi árnyékban - sőt a helyzet itt és általában véve is kedvezőtlenebb, mint az ugyancsak alföldi szomszédos Hajdú-Bihar megyében. Az úthálózat korszerüsítése során messzemenően figyelembe kellene venni ezt a körülményt, törekedve arra, hogy minél több településnek javuljon a jelenleg még meglehetősen kedvezőtlen forgalmi helyzete. Mátészalka és környezete gazdaság- és településföldrajzi pozícióját jelentős mértékben javítaná, a város decentrum illetve körzetközpont szerepét erösítené, ha az M3-as autópálya megvalósulna, és a mintegy 50 települést és 100 ezer lakost magában foglaló Záhony és Térsége Vállalkozási Övezet tevékenysége révén, a Nyíregyháza-Kisvárda-Záhony országos térszerkezeti tengely mentén húzódó, dinamikusan fejlődỏ és egyre szélesedő „gazdasági korridorhoz" szorosabb szálakkal kapcsolódhatna a formálódó Nyírbátor-Mátészalka-Fehérgyarmat tengely (4., 5., 6. ábra).

A rossz megközelithetöség azonban nem pusztán a helyi lakosok életében jelent kényelmetlenségeket, hanem a térség gazdasági lehetöségeit is alapjaiban érinti. A sikeresen lezajlott privatizációk óta gyakorlatilag nem történt jelentős munkahelyteremtő beruházás, és ez nem kismértékben ennek a tényezönek köszönhető. Mindenképpen javítani kell tehát mind a vasúthálózat, mind a közutak minöségén és forgalmi kapacitásán, mert a közelgő Uniós csatlakozás esetén jelentősen növekedni fog az egész régió szerepe (a Zeiss számára nagy lehetöséget jelent a határőrségnek a schengeni elvárásoknak megfelelő szintü speciális optikai felszerelésekkel 
való ellátása), és ez a kedvezőtlen adottság jelentősen visszavetheti a termelés további felfuttatását vagy az esetleges újabb befektetók érdeklódését.

A továbbfejlödéshez pedig mindenképpen elengedhetetlen a külföldi töke részvétele a térség gazdaságâban, mert a hazai vállalkozók tőkeszegénysége gátolja a fejlesztési elképzelések megvalósítását valamennyi nemzetgazdasági ágban. Ebben a tekintetben Mátészalka jó alapokról indulhatott (a XIX. század végi, majd a Trianon utáni és a szocialista iparfejlesztések), és az 1990-es évek elején lezajlott privatizáció is nagyon sikeresen valósult meg. Az idetelepült cégek magas technológiai színvonalat képviselnek, és a helyi kötődésü ügyvezetők garanciát jelentenek arra, hogy a vállalatok továbbra is támogatni fogják a város fejlesztését (infrastruktúra, környezetvédelem, kulturális alapítványok stb.).

A minél több új befektető megszerzése mellett tehát szükség van - és lesz a jövőben is - a jó kapcsolatok ápolására a már jelenlévő cégekkel. Egyik képviselöjük szerint ebben sokat segítene az, ha a mostaninál több beleszólásuk lehetne a város irányításába. Mindenképpen szükség lenne egy jó cselekvési program alapjául szolgáló városfejlesztési tervre, és ennek kidolgozásába a lehetö legnagyobb mértékben be kellene vonni a helyi gazdaság képviselöit. Ez azért lenne indokolt, mert így közeledhetnének egymáshoz a város és az ipari parkban letelepült üzemek álláspontjai, melyek néhány fontos kérdés megitélésében eltérőek. A cégek szeretnék, ha több pénzt forgatnának vissza a befizetett adókból a szerintük elégtelen ipari háttér-infrastruktúra fejlesztésére, és szeretnének beleszólni a képzési struktúra számukra minél megfelelőbb átalakításába.

Az oktatási rendszer szerkezetének átalakitására kétségkiviul szükség van, mivel a még mindig nagyon magas (17\% körüli) munkanélküliségi ráta miatt alaposan meg kell gondolni, hogy van-e értelme olyan szakmákban történö oktatásra, ahol kereslet hiányában csak a pályakezdô munkanélküliek újratermelése folyik. Tény, hogy vannak olyan képzési irányok a városban, amelyek esetében eröteljesen felborult a keresleti és a kínálati oldal kényes egyensúlya. Figyelembe kell venni azonban azt a tényt, hogy az egyes iskolák képzési irányvonalainak átalakítása rengeteg pénzbe kerül, és korántsem biztos, hogy a megfelelố eredményt hozza (szinte lehetetlen hosszú évekre elöre meghatározni a biztosan keresett szakmákat, mert a képzés beindításának csak tartós és megfelelö szintủ kereslet esetén van értelme). Az iskolák véleményünk szerint megtették a kellő lépéseket, mivel lehetőségeihez mérten mindegyikük próbál modern, keresett képzettséget nyújtó szakirányokat biztosítani tanulói számára. Ez akkor is vitathatatlan, ha ezek nem mindig esnek egybe a helyi vállalatok szükösebb, az iskolák átalakulási képességénél gyorsabban változó igényeivel. Ebben leginkább a munkaügyi kirendeltség átképző tanfolyamai jelenthetnek segítséget, de ezek eléggé szúkös keretek között fejthetik ki hatásukat (csak a regisztrált munkanélküliek számára elérhetőek).

A munkaerő-piaci egyensúlyt azonban nem lehet pusztán a pályakezdő fiatalok megfelelöbb képzésével helyreállítani, mert ez annál sokkal összetettebb probléma. A magas munkanélküliség legnagyobbrészt a szocialista nagyvállalatok összeomlá- 
sa utáni hagyaték, de a közintézmények létszámcsökkentései és az orosz gazdasági válság következményeként bekövetkezett leépítések miatt még napjainkban is növekszik (az állástalanok létszáma Mátészalkán tartósan meghaladja az 1000 föt). A magas munkanélküliség jelenti a legnagyobb társadalmi problémát a térségben, mert szinte mindegyik családot érinti valamilyen formában, és negatív hatásai további szociális feszuiltségek forrásává teszik. Ahogyan a fentebb leírtak bizonyítják, a keleti országrész egészéhez hasonlóan itt sem sikerült megoldani a gondokat, pusztán tüneti kezelésröl beszélhetünk.

A hatékony megoldásokra pedig nagy szükség lenne. A tartósan munkanélküli szakképzett munkaerö értéke rohamosan csökken (megkopik a tudás és a munkafegyelem), és ezeket az embereket fenyegetik leginkább a szenvedélybetegségek és a végleges lecsúszás veszélye. Az állástalanok magas száma a lakosság által befizetett személyi jövedelemadó csekélyebb összegein keresztül csökkenti a helyben képződö forrásokat, és a segélyezés is nagyon sok pénzbe keruil. Emellett az etnikai problémák felszinre kerülése is fenyeget, hiszen a térségben élő romák mintegy 70\%-a tartósan kiszorult a munkaerőpiacról, és ebben szerepe van a diszkriminációnak is.

A problémák megoldásának egyetlen igazán hatásos módja a munkahelyteremtés lenne, de ez a jelenlegi helyzetben számos akadályba iitközik. A sikeresen lezajló privatizáció óta a külföldi tőke érdeklödése nagyon mérsékelt a térség iránt, és a Zeiss fejlesztéseitől eltekintve nem történt jelentős munkahelyteremtö beruházás sem. A helyi kis- és középvállalkozások körében tapasztalható ugyan fejlődés, de a legtöbb csak egy-két emberrel képes növelni alkalmazotti létszámát, és ez a munkaerőpiacon alig érzékelhető. A jelenlegi helyzet megváltoztatásának egyik lehetséges módja a külföldi (vagy hazai) tőke figyelmének felkeltése a helyi adottságok (ipari park, nagy tömegü olcsó és szakképzett munkaerő) iránt, és a tőkebeáramlás feltételeinek további javítása. A másik lehetöség a helyi vállalkozások megerősítése, hogy minél jobb lehetőségeik legyenek a már jelenlévő cégeknek történő beszállítói tevékenységre. Az együttmúködés alapjait lefektették már, de jelenleg meglehetösen nagy különbség van a cégek és a beszállítók technológiai színvonala között, és a kapcsolatok a jövöben csak ennek mérséklödése esetén bỏvíthetök. Mindkét esetben elsörendü fontosságú azonban, hogy a helyben termelödö szellemi bázist, vagyis a szakképzett munkaeröt itt tartsák, a lehető legkisebbre csökkentve a szelektív elvándorlás káros hatásait.

A helyi értelmiség megtartása nem pusztán gazdasági érdek, hanem a helyi társadalom összetétele, aktivitása, cselekvőképessége szempontjából is kulcskérdés különösen a falvak esetében. A legnagyobb cselekvőkészség ugyanis ezt a csoportot jellemzi (a megfelelö életkörülmények megléte esetén), de - a megkérdezettek véleménye alapján - jelenleg inkább a mindennapi megélhetési gondok kerültek elötérbe, ez pedig a közösségi élet iránti közömbösséget vonja maga után. Ez ellen próbálnak tenni valamit a létrejött civil szervezetek, de eredményeik ma még eléggé korlátozottak. Bizonyitja ezt az országgyủlési és az önkormányzati választásokon való csekély részvétel, vagyis a helyi politikába, a települések jövójébe való bele- 
szólás egyre mérséklődő igénye. Pedig a térség dinamikus fejlődése eddig is elképzelhetetlen volt hasonlóan dinamikus társadalom nélkül, és ez a következỏ évezredben sem lesz másképp. Ezért a lehetö legnagyobb támogatásban kell részesíteni azokat a szervezeteket, amelyek a társadalmi közömbösség ellen kívánnak fellépni, bár az igazi megoldást az jelentené, ha létrejöhetne egy biztonságos anyagi háttérrel rendelkező, húzóerőt jelentő középosztály.

Jelen pillanatban még nincs érzékelhető feszültség az egyes társadalmi csoportok között, de vannak a jövőre nézve aggasztó tendenciák. Ilyen fenyegető veszély a társadalom polarizálódása, a jövedelmi különbségek növekedése miatti feszültségek felszínre kerülése. Sajnálatos módon a jövőben sem a gyors meggazdagodás miatt nő majd a távolság az egyes rétegek között - a térségben ugyanis még nem alakult ki szorosabb értelemben vett és irritálóan fényüzó életmódot folytató gazdasági elit -, hanem a fokozatos elszegényedés miatt (az egy före vetített helyi adó 7000 forintot tett ki 1997-ben, és már nemigen emelhető tovább). Ez nem pusztán a magas szintú munkanélküliség, hanem a cigány népesség fokozatosan növekvő aránya miatt is elöre prognosztizálható. Emiatt valószinuúleg néhány településen az etnikai problémák megjelenésével is számolni kell majd, bár jelen pillanatban általában harmonikusnak nevezhetö az együttmüködés a kisebbségi szervezetekkel; a gondok ma még csak a magasabb arányú cigány népességgel rendelkező falvakban jelentkeznek, ahol ez általában elriasztja a betelepülni szándékozókat.

A térség településeinek külső megitélése nemcsak ebből a szempontból fontos, hanem az idegenforgalom szempontjából sem nevezhetö mellékesnek. Ebben az ágazatban pedig nagy lehetőségei vannak „Szatmár fövárosának”, ahogyan azt a múltat felidéző statisztikai adatok is bizonyítják. Ahhoz, hogy a rendszerváltás elötti szintet ủjra el tudja érni, még nagyon sok belső és külső körülménynek meg kell változnia. A legfontosabb helyi tennivaló, hogy nemcsak az itteni lakosság, hanem a külső szemlélő számára is vonzóvá kell tenni a várost és környékét. Ennek megfelelően a turisztikai igényeket kiszolgáló szállás- és vendéglátóhelyek fejlesztése mellett nagy figyelmet kell fordítani a városképre is. A văros egyetlen igazán ismert müemléke a régi református templom, ezért nagy jelentőséget kell tulajdonítanunk a Kocsis-Hauser Alapítvány tevékenységének, amely nagyon szép és egyedi köztéri szobrok állitásával próbál egyéni, könnyen felismerhetö arculatot adni a településnek.

Sokat lendithetne Mátészalka egyébként pezsgő kulturális életén és idegenforgalmán, ha sikerülne létrehozni egy, a nyírbátori Szárnyas Sárkány Napokhoz hasonló horderejủ rendezvényt, amit jelenleg nagyon hiányol a város. Az idegenforgalom fellendítésének azonban ezen kívül is megvannak a lehetőségei (a Szatmári Múzeum kocsigyüjteménye és egyéb kiállításai, a termálfürdő gyógyturisztikai jellegú fejlesztése, színházi élet stb.), így a település az eddig nem igazán ismert szatmári vidékekre irányuló turizmus központjává is válhatna. Ehhez viszont nem elegendỏek pusztán a belső törekvések és a jobb önmenedzselés: kell hozzá egy fizetőképes bel-, illetve külföldi kereslet. A szomszédos országok jelenlegi helyze- 
tét figyelembe véve azonban a közeljövőben nem kell kezelhetetlenül nagy tömegú látogatóra számítani, a hazai turisták számát pedig alaposan visszaveti a térség nagyon rossz elérhetősége.

A térség további fejlődésében a legfontosabb szerep mindenképpen a helyi önkormányzatoknak jut majd. Egyrészt azért, mert a fentebb felsorolt területeken meglévő, a fejlődést hátráltató gátak felszámolása és az adottságok minél jobb kihasználása nagymértékben függ a testületek tevékenységétỏl is. Másrészt az Európai Unióhoz való csatlakozás esetén a térség elött hatalmas lehetöségek nyilhatnak meg, és sok függ attól, hogy az önkormányzatok mennyit tudnak majd kiaknázni ezek közül. A csatlakozás után itt, a hármas határ mentén húzódik majd az Unió keleti határa, és ebben az esetben a települések számíthatnak az elmaradott határ menti térségeknek juttatott támogatásokra, amelyek hatalmas forrást jelenthetnének a szükséges fejlesztésekre, a fejlettebb területekhez való felzárkózásra. Ezekre a forrásokra pedig mindenképpen szükség lesz, mert a térség önerőből már ma sem képes ezek előteremtésére, és a jelenlegi tendenciák megmaradása mellett a jövőben is külső támogatásra lesz utalva.

A tényleges sikerekhez azonban elengedhetetlenül szükség lesz az önkormányzatok eddigi agilitásának megörzésére (sőt fokozására), és a térségre vonatkozó szilárd fejlesztési irányelvek kidolgozására. Ez azonban csak abban az esetben képzelhető el, ha a jelenleginél nagyságrendekkel jobb lesz az egyes települések közötti együttmüködés, mert a régiók Európájában a napjainkban tapasztalhatónál sokkal fontosabb szerepe lesz a térségi fejlesztéseknek. Ezek viszont csak akkor lehetnek eredményesek, ha az esetleges múltbeli sérelmeket félretéve sokkal tágabb teret kap az együttilletve egymásért való gondolkodás. Nagy szerepe lesz annak is, hogy az önkormányzatok vezetői tudnak-e függetlenedni a négyéves ciklusoktól, és tudnak-e hosszabb távon is gondolkodni településeik érdekében. Nagyon fontossá válhat a jövőben a külső kapcsolatok megfelelő ápolása, a testvérvárosokkal (Munkács, Nagykároly, Zevenaar, Vittoria) való minél eredményesebb gazdasági és kulturális együttmüködés. Ezt szolgálja napjainkban a jól müködő diákcsere-program, valamint a minden év szeptemberében megrendezett Szatmár Expo Általános Kiállítás és Vásár, de vannak még további kiaknázható lehetőségek is e téren.

Nagy lehetỏséget hordoz magában a jövőre nézve, hogy a város gazdasági erejét tovább lehet növelni a Nyírbátor-Mátészalka-Fehérgyarmat erövonal céltudatos fejlesztésével, a kapcsolatok minél szorosabbra füzésével. Központi szerepköre miatt ebben a tekintetben Mátészalkára hárul a legnagyobb felelösség, de bízvást számítani lehet az erőfeszítések megtérülésére, amennyiben sikerül megőrizni a vezetö szerepet, és az elhatározáson túl tényleges tartalommal megtölteni az együttmüködést. Ez azért különösen fontos, mert az EU keleti határvidékén szükség lesz egy sikeres, stabil kapcsolatokkal rendelkező, a fentebbi városok alkotta gazdasági-kulturális gócpontra, amely meghatározhatja az egész régió fejlődését. Együttes fellépés esetén nemcsak az Uniós támogatásokra lehet nagyobb eséllyel pályázni, hanem (kihasználva a terület földrajzi fekvését) a remélhetỏleg minél 
hamarabb stabilizálódó és fizetőképessé váló hatalmas kelet-európai piacokra is könnyebb lenne betörni.

Ehhez viszont elengedhetetlen a kormányzati szintü támogatás, mert számos olyan feladat van, amit a városok együrttesen sem lesznek képesek megvalósítani. Ezek között első helyen kell említeni a szomszédos országokkal való közlekedési kapcsolatok európai színvonalra történö emelését. Ennek érdekében modernizálni kell a határ menti közutakat, növelni kell a meglévő határátkelök kapacitását, illetve új határátkelök épitésére is sziikség lenne már a mai viszonyok között is. A kormányzat segítségére az anyagi támogatáson túlmenően a szomszédos országokkal való legmagasabb szintü egyeztetés terén van a legnagyobb szükség, mert tényleges fejlődésröl csak akkor lehet majd beszélni ebben a régióban, ha sikerül azonos hullámhosszra hangolni az egyes országok határ menti területeikre vonatkozó fejlesztési elképzeléseit.

Összességében megállapíthatjuk, hogy Mátészalkának és közvetlen környezetének minden esélye megvan arra, hogy a jelenlegi kissé ellentmondásos fejlödést a jövöben egyértelmü sikerességgé változtassa. Olyan sikerességgé, amely nem csupán a jelenleg kritikus helyzetben lévö Északkelet-Magyarországhoz képest mérhetö, hanem az ország egészéhez viszonyítva is számottevö lehet. Ehhez azonban jól kell sáfárkodni a meglevö adottságokkal, és ez valamennyi település vezetöinek és polgárainak együttes érdeke, ugyanakkor együttes felelössége is. Ha sikerül felismertetni a közös érdekeket, és megegyezö hullámhosszra hozni a felelös vezetök fejlesztési elképzeléseit, akkor a térség nagyon szép reményekkel indulhat neki a minden bizonnyal eredményes XXI. századnak.

A sikeres települések - városok és falvak - száma nemcsak Magyarországon, hanem Észak-és Kelet-Magyarországon is egyre növekszik. Van, ahol még szigetszerüen jelentkeznek, van, ahol fejlett régiókká, fejlödési tengelyekké formálódnak össze. Minél több város lép a sikeresek közé, annál közelebb jutunk a sikeres Magyarországhoz. Mindenfajta terület-és vidékfejlesztési politikának nagy figyelmet kell forditania tehát a település-siker támogatására. Ebböl a szempontból is tanulságos, s részben megnyugtató Mátészalkának és környezetének a példája.

\section{Jegyzet}

' A tanulmány az OTKA T 023004. számú kutatási program keretében készültt.

\section{Irodalom}

Baranyi B. (szerk.) (1999) Északkelet-Magyarország és a határok. Északkelet-Alfold határ menti területeinek helyzete - a felzárkózás lehetõségei és esélyei. Az MTA Stratégiai Kutatások Az Alföld II. kutatási program, Új környezeti, gazdasági, települési és társadalmi folyamatok az Alföldön címủ alprogram 2. tudományos részjelentése. Debrecen, MTA RKK ATI Debreceni Csoportja.

Baranyi, B.-Balcsók, I.-Dancs, L.-Mezö, B. (1999) Borderland Situation and Periferality in the NortbEastern Part of the Great Hungarian Plain. Discussion Papers, 31. Pécs, Centre for Regional Studies. Cservenyák L. (szerk.) (1984) Szabolcs-Szatmár. Magyarország megyéi. Budapest, Kossuth. 
Csordás L. (1999) Területi különbségek az Északkelet-Alföld határmenti területein. ÉszakkeletMagyarország és a határok. Északkelet-Alföld határ menti területeinek helyzete - a felzárkózás lehetöségei és esélyei. - Baranyi B. (szerk.) Debrecen, MTA RKK ATI Debreceni Csoportja. 47-110. 0.

Enyedi Gy. (1995) Városverseny, várospolitika, városmarketing. - Tér és Társadalom. 1-2. 1-3. o.

Enyedi Gy. (1996) Regionális folyamatok Magyarországon. Budapest, Hirscher Rezsö Szociálpolitikai Egyesület.

Enyedi Gy. (1997) A sikeres város. - Tér és Tărsadalom. 4. 1-7. o.

Frisnyák S. (szerk.) (1998) Szabolcs-Szatmár-Bereg megye monográfiája 2. Társadalom és gazdaság. Nyíregyháza.

Kasza Sándor (sorozatfőszerk.) (1998) Szabolcs-Szatmár-Bereg megye kézikönyve. (Magyarország Megyei Kézikönyvei 15. köt.). Kaposvår, Ceba Kiadó.

Szabó M. (1975) Szabolcs-Szatmár megye és városai. Magyarország megyéi és városai. - Kulcsár V.Lackó L. (szerk.) Budapest, Kossuth.

\section{MÁTÉSZALKA, THE SUCCESSFUL CITY - IS IT A REAL SUCCESS, OR JUST A HOPING BREAKING THROUGH ATTEMPT?}

\section{BÉLA BARANYI - ISTVÁN BALCSÓK}

The present study examines the causes and the factors of success. It contains the main results of the analysis of the city of Mátészalka and two settlements of its agglomeration zone (Jármi and Ópályi). The study shows the last, the present and the future developments opportunities of the city and the two settlements in the base of statistical data, writings and surveys and interviews. The remarkable success is extremely relative at present even in the case of Mátészalka. It has only a quite occasional influence on its near surroundings. We could hardly speak about a real break through or an upsurge including the whole of the local social-economic sphere.

The aim of the analysis based on the available data was the following questions: The cities and its surroundings standing a chance for development can really show the unbroken signs of development for future? Do they have the fundamental factors of successfulness? Answering these questions is especially important in our case because Mátészalka has the notes of successfulness in a more underdeveloped region than the Great Plain. Deciding if the city is successful in comparison its closer surroundings or in comparison to the whole Great Plain has great importance. In the last case it could be able to promote the renewing of the whole Szabolcs-Szatmár-Bereg county. 